ARTICLE

\title{
Earth's oldest mantle fabrics indicate Eoarchaean subduction
}

Mary-Alix Kaczmarek ${ }^{1,2}$, Steven M. Reddy ${ }^{2}$, Allen P. Nutman ${ }^{3,4}$, Clark R.L. Friend $^{4,5}$ \& Vickie C. Bennett ${ }^{6}$

The extension of subduction processes into the Eoarchaean era $(4.0-3.6 \mathrm{Ga})$ is controversial.

The oldest reported terrestrial olivine, from two dunite lenses within the $\sim 3,720 \mathrm{Ma}$ Isua supracrustal belt in Greenland, record a shape-preferred orientation of olivine crystals defining a weak foliation and a well-defined lattice-preferred orientation (LPO). [001] parallel to the maximum finite elongation direction and (010) perpendicular to the foliation plane define a B-type LPO. In the modern Earth such fabrics are associated with deformation of mantle rocks in the hanging wall of subduction systems; an interpretation supported by experiments. Here we show that the presence of B-type fabrics in the studied Isua dunites is consistent with a mantle origin and a supra-subduction mantle wedge setting, the latter supported by compositional data from nearby mafic rocks. Our results provide independent microstructural data consistent with the operation of Eoarchaean subduction and indicate that microstructural analyses of ancient ultramafic rocks provide a valuable record of Archaean geodynamics.

\footnotetext{
${ }^{1}$ Institute of Earth Sciences, University of Lausanne, UNIL-Mouline, Building Geopolis, CH-1015 Lausanne, Switzerland. ${ }^{2}$ Department of Applied Geology, ARC Centre of Excellence for Core to Crust Fluid Systems (CCFS) and the Institute For Geoscience Research (TIGeR), Curtin University, GPO Box U1987, Perth, Western Australia 6845, Australia. ${ }^{3}$ GeoQuEST Research Centre, School of Earth and Environmental Sciences, University of Wollongong, Wollongong, New South Wales 2522, Australia. ${ }^{4}$ Beijing SHRIMP Centre, Institute of Geology, Chinese Academy of Geological Sciences, 26 Baiwanzhuang Road, Beijing 100037, China. ${ }^{5}$ Glendale, Oxon OX9 2LQ, UK. ${ }^{6}$ Research School of Earth Sciences, The Australian National University, Mills Road, Canberra 0200, Australia. Correspondence and requests for materials should be addressed to M.-A.K. (email: mary-alix.kaczmarek@unil.ch).
} 
$\mathrm{n}$ the Phanerozoic Earth ( $\sim 540 \mathrm{Myr}$ to present day), subduction is a major component of global plate tectonics and is the most significant mechanism for recycling material, including water and other volatiles, from the surface into the deep Earth ${ }^{1,2}$. This has had a profound effect on Earth's geological, geochemical and geophysical evolution. However, the timing of the initiation of subduction, and its role in shaping Precambrian Earth evolution, particularly within the Archaean Eon $(4,000-2,500 \mathrm{Myr})$ is highly controversial ${ }^{3,4}$. One approach to understanding Archaean geodynamics is to model the behaviour of the lithosphere ${ }^{5}$. However, an alternative, and complementary approach is direct observation of Earth's oldest rock suites. The Isua Supracrustal Belt (ISB) of southern West Greenland comprises some of Earth's oldest, best preserved rocks and these rocks can yield unique data that allow ancient geological processes to be inferred ${ }^{6,7}$. The ISB escaped significant deformation in the Neoarchaean, but most of it is still strongly deformed due to Eoarchaean deformation ${ }^{8-10}$. At its northwestern end, the ISB consist of several fault-bounded lithotectonic sequences containing rocks inferred to have formed in an island arc setting. These include pillowed and flow basalts, gabbroic layers, boninites and chemical sedimentary rocks including band iron formation ${ }^{7,8,11}$ (Fig. 1a,b).

The eastern side of the northwestern end of the ISB contains a suite of strongly deformed ophiolitic rocks, comprising mantle peridotite lenses, gabbros and related cumulate ultramafic rocks, pillow lavas and chemical sedimentary rocks $^{6}$ (Fig. 1). Geochemical analyses of the magmatic components of these ophiolitic rocks are consistent with an arc and sub-arc setting that formed around 3,720 Myr ago 6,7,12 (Fig. 1).

Within one strand of ultramafic schists there are two laterally extensive, relatively unaltered, magnesian dunite bodies (lenses A and B; Fig. 1b-d). Rocks within the dunite bodies have chemical characteristics that distinguish them from other types of ultramafic rocks, including those formed as olivine cumulates, which are also found within the $\mathrm{ISB}^{13}$. These dunites comprise forsteritic olivine and chromite but are plagioclase and garnet free indicating equilibration at $<2.0 \mathrm{GPa}$ and above $\sim 850^{\circ} \mathrm{C}$ (ref. 14).

Lenses A and B preserve macroscopic high-temperature fabrics defined by the alignment of olivine grains (Figs 1c,d and 2a). Field relationships demonstrate these olivine fabrics predate the schistosity formed during juxtaposition of the dunites with adjacent crustal rocks and subsequent intra-crustal deformation under lower amphibolite facies conditions $\left(\leq 550^{\circ} \mathrm{C}\right)$. The spatial association of lenses $\mathrm{A}$ and $\mathrm{B}$ with volcanic rocks with arc geochemical signatures, the tectonic contact between peridotite and adjacent rocks, their chemical compositions and the constraining $\mathrm{U}-\mathrm{Pb}$ zircon geochronology has led to an interpretation that these lenses represent sub-arc mantle interleaved with supra-subduction ophiolitic material during the Eoarchaean era $6,13,15$

Here we study the microstructure and the lattice-preferred orientations (LPO) of olivine preserved in lenses of ISB mantle rocks using electron backscatter diffraction (EBSD). The microstructural data indicate fabric formation associated with dislocation creep and indicate the preferential activation of (010)[001] B-type slip system ${ }^{16,17}$. B-type fabrics have only been observed in mantle rocks and experimentally are restricted to relatively high stress, high pressure and high water content deformation conditions ${ }^{16-21}$. Their presence within Phanerozoic rocks is interpreted to indicate supra-subduction zone mantle deformation and this discovery of B-type fabrics in Earth's oldest mantle rocks suggest that the subduction was already active in the Eoarchaean era.

\section{Results}

Petrography. Two samples (G07/10 and G12/12) from lens A and a single sample from lens B (G07/32) were analysed (Fig. 1). Lens $\mathrm{A}$ is dominated by homogeneous dunite with a granular texture and olivine grains that range from 0.5 to $1.0 \mathrm{~mm}$ in maximum length and define a weak shape-preferred orientation (Fig. 2b). The samples contain $>90 \%$ olivine $\left(\mathrm{Fo}_{91-92}\right)$ with

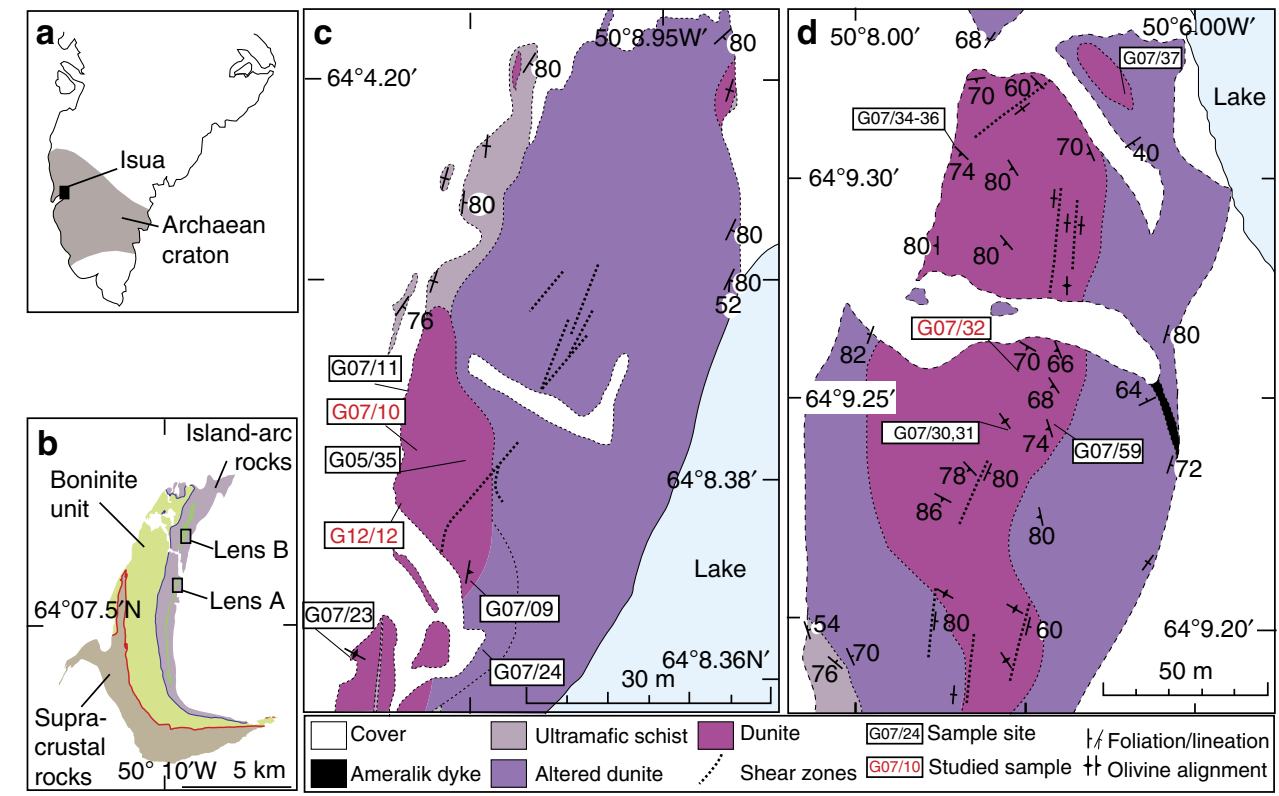

Figure 1 | Maps of Greenland and Isua supracrustal belt. (a) Southern part of Greenland and location of Isua. (b) Outline of the northwestern part of the Isua supracrustal belt (ISB) and location of ultramafic bodies (purple and pink), lenses A and B, within ca. 3,720 Ma island arc mafic rocks (mauve). (c,d) Detailed maps of preserved ultramafic rocks for lenses A and B, respectively. Lens A, at GPS 6508.382 N, 50 09.011 W and lens B, at GPS 6509.256 N 5008.704 W (using World Geodetic System, WSG84 map datum). 


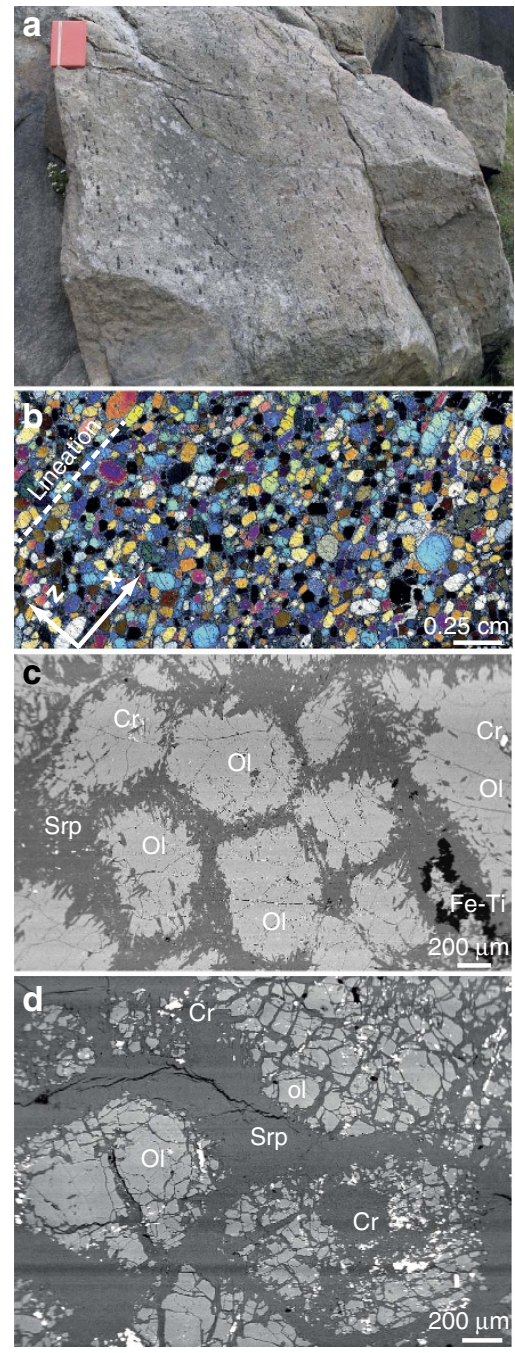

Figure 2 | Texture of Isua dunite peridotite. (a) Picture of anhydrous peridotite with olivine megacrystals showing a preferred orientation, lens $B$. (b) Cross-polarised microphotograph of a thin-section sample G12/12 from lens $A$ with lineation (dashed-line). $X$ represents the lineation and $Z$ the normal to the foliation. Scale bar, $0.25 \mathrm{~cm}$. (c) Backscatter (BSE) picture of olivine grains with serpentine matrix in sample G07/10 from lens A. Scale bar, $200 \mu \mathrm{m}$. (d) BSE picture of olivine grains with serpentine in sample G07/32 from lens B. Scale bar, $200 \mu \mathrm{m}$. Cr, chromite; OI: olivine; Srp, serpentine.

retrograde chlorite, serpentine and minor magnetite developed along the grain boundaries during a younger crustal metamorphic event (Fig. 2c) ${ }^{12}$. Both samples from lens A have a macroscopic foliation and lineation corresponding to the XY plane and the $\mathrm{X}$ direction, respectively, of the principal axes of the finite strain ellipse. Foliation and lineation are observed at both hand and thin-section scale (Fig. 2b). The dunite from lens B (sample G07/32) also has a granular texture but is characterized by brown olivine $\left(\mathrm{Fo}_{96-98}\right)$ with grains from 0.4 to $0.8 \mathrm{~mm}$ in maximum length $^{12}$ (Fig. 2d). Similar to lens A, this sample contains retrograde serpentine and magnetite. At the hand specimen scale, this sample has no discernable macroscopic foliation or lineation. We have, therefore, undertaken X-ray computed tomography (X-ray CT) on this sample to determine the foliation plane and lineation orientations (see Methods Summary for X-ray CT protocols). X-ray CT images of the sample in multiple orientations have been created with a relatively high contrast to

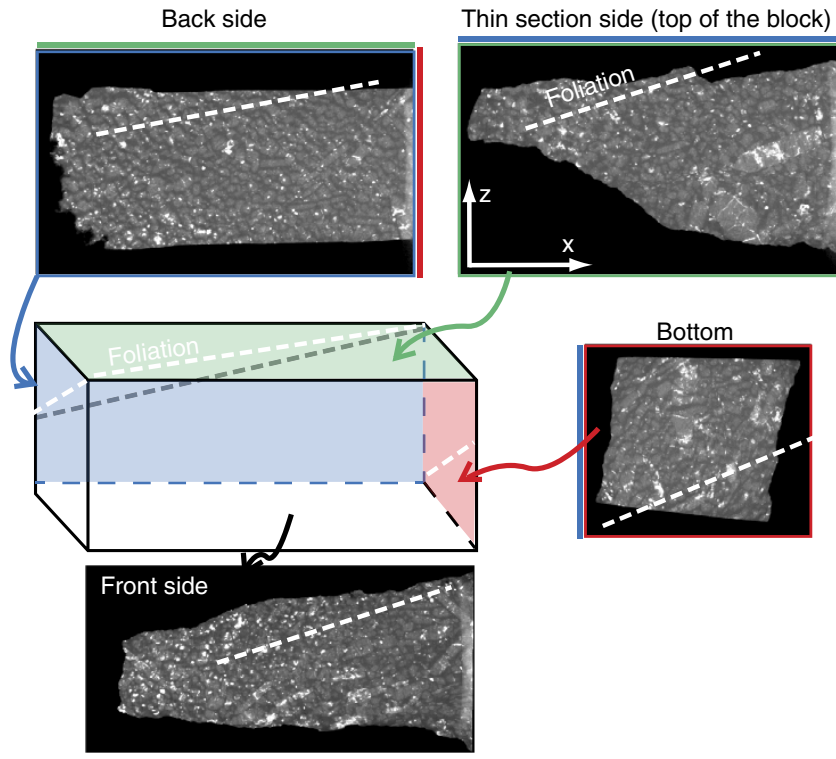

Figure 3 | Three-dimensional representation of sample G07/32 using four images from computer tomography. The block is a schematic view of the piece of dunite where have been cut the thin section. The top of the block (green) corresponds to the thin-section side, the backside is blue, the bottom side is red and the front size is colourless. The white dashed-lines represent the inferred foliation plane within the four sides.

highlight the density difference between matrix serpentine and olivine grains and recognise shape-preferred orientations in the olivine grains (Fig. 3). Using this approach, a weak foliation and lineation can be determined (Fig. 3). These are used to define the sample coordinate framework needed to constrain fabric type from the EBSD data.

Microstructures. We have characterized the deformation microstructures and LPO preserved in olivine within lenses A and $B$ of the ISB mantle dunites using EBSD (see Methods section for EBSD collection protocols). Fabric data from lens A show alignment of [001] olivine axes with the macroscopic lineation $(\mathrm{X})$ and $[010]$ axes show a strong alignment perpendicular to the sample foliation (XY) and parallel to the $\mathrm{Z}$ direction of the finite strain ellipse (Fig. 4a,b). [100] axes show no clear preferred orientation (Fig. 4a,b).

The sample from lens B (G07/32) also records a strong alignment of [010] axes, perpendicular to clustered [001] axes and a very weak [100] distribution (Fig. 4c). X-ray CT data show that [010] axes are perpendicular to the foliation plane with [001] parallel to the weak lineation. These relationships mimic those observed in both samples from lens A (Fig. 4a,b). To assess the similarity and compare the nature of the fabrics between samples from lenses A and B, we have rotated the data from lens $\mathrm{B}$ to align [001] axes (lineation) to $\mathrm{X}$ and [010] to Z (Fig. 4d). Reorientation of CPOs is frequently used in unoriented samples such as peridotite xenoliths and coarse-grained peridotite when lineation/ foliation is difficult to determine, as this facilitates comparison of the data ${ }^{22,23}$. The result of the applied rotation highlights a clear similarity between olivine fabric geometry and intensity between the samples from lenses $\mathrm{A}$ and $\mathrm{B}$.

\section{Discussion}

The observed alignment of olivine crystallographic [001] axes parallel to the lineation $(\mathrm{X})$ and the strong concentration of [010] parallel to $\mathrm{Z}$ in the dunites are characteristic of B-type olivine 


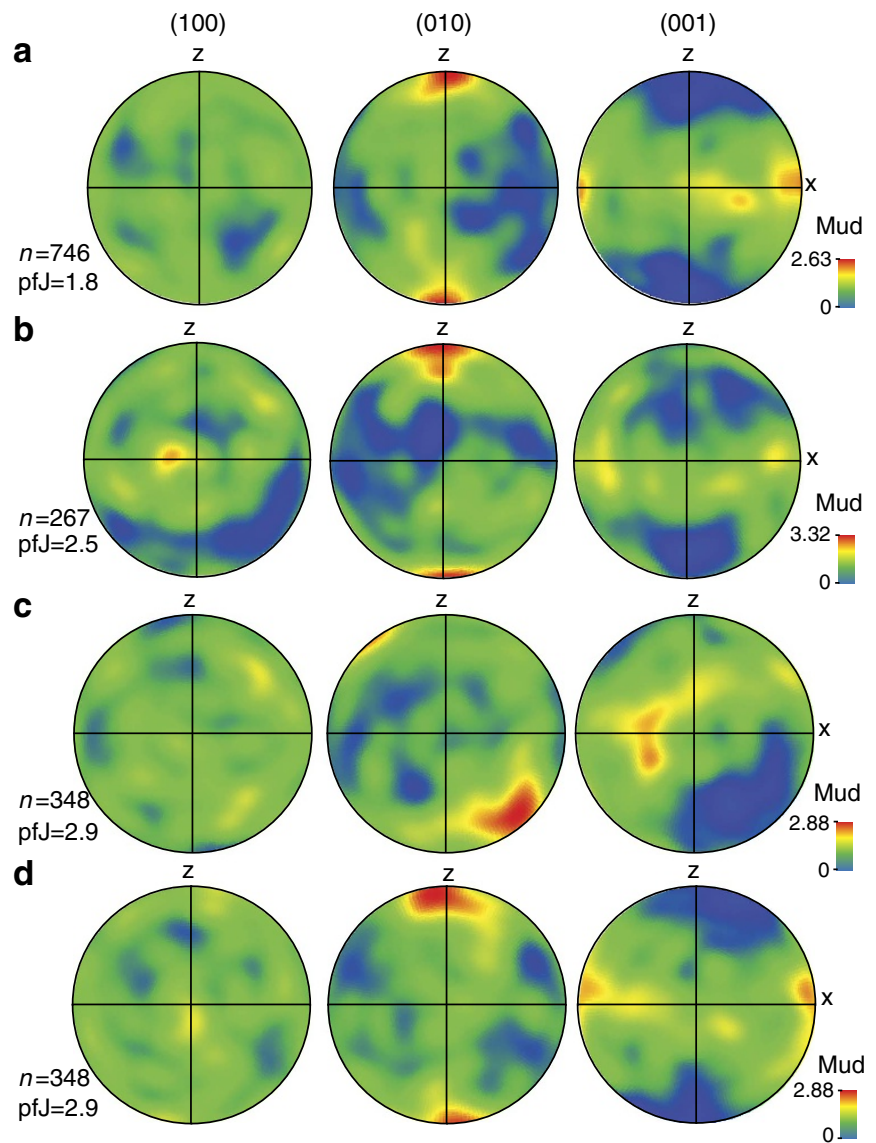

Figure 4 | Crystal preferred orientations patterns of olivine in three Isua dunites. (a) Lens $A$, sample G12/12; (b) Lens A, sample G07/10; (c) Lens $B$, sample G07/32; (d) Lens B, sample G07/32. (c,d) represent the same sample (G07/32) with a rotation applied on $\mathbf{d}$ to align [001] axes to X. See text for explanations. Contoured pole figures are lower hemisphere, equal area projections. Samples are represented in the structural reference frame where $X$ represents the lineation and $Z$ the normal to the foliation. mud, multiples of uniform distribution; $n$, number of measured grains per sample.

fabrics associated with mantle deformation dominated by the operation of (010)[001] (B-type) slip system ${ }^{16,17,21}$. The intensity of olivine B-type fabrics recorded here are quite weak with a J-index varying from 1.8 to 2.9 (Fig. 4; see Methods Summary for J-index explanations and reference). These values are similar to B-type fabrics observed in $\operatorname{most}^{16,20,21,24}$, but not all ${ }^{17}$ experiments, and in several natural peridotites ${ }^{25-29}$. Although, we note that some natural peridotites record strong olivine B-type fabrics ${ }^{30-34}$, these are no more common than weaker peridotite B-type fabrics ${ }^{25-29}$

Deformation of this kind has only been reported in ultramafic rocks of mantle origin. However, B-type fabrics have been experimentally produced under moderate to high water, high temperature, pressure and high stress conditions (200-2,129 p.p.m. H/Si water content, 1.6-11 GPa, $~ 1,000-1,400{ }^{\circ} \mathrm{C}$, $150-516 \mathrm{MPa}$, respectively) $)^{16,17,19-21,35,36}$. Modelling predicts the formation of B-type fabrics under such conditions, and such conditions are predicted to be present in the fore-arc mantle wedge immediately overlying the slab in supra-subduction zone environment ${ }^{37}$. This contrasts with the core of the mantle wedge, where (010)[100] (A-type), (100)[001] (C-type) or (001)[100] (E-type) fabrics are more likely ${ }^{37}$. Seismic anisotropy measurments that indicate trench-parallel alignment of seismic fast directions in supra-subduction fore-arc regions are consistent with the development of B-type fabrics in these settings ${ }^{16,37}$. Furthermore, the few examples of naturally occurring B-type olivine fabrics are mostly associated with mantle peridotites exhumed from supra-subduction settings such as in the Central Alps (Cima di Gagnone and Val Malenco) ${ }^{26,29,38}$, CarpathianPannonian region ${ }^{30}$, north Qilian mountains in $\mathrm{China}^{39}$, Shanwang in Eastern China ${ }^{27}$, Higashi-Akaishi, Japan ${ }^{31,33,34}$, the Happo region of Central Japan ${ }^{40}$, the southern Marian trench $^{28}$, southwest Norway ${ }^{25,32,41}$ and New-Zealand ${ }^{42}$. The exception is the formation of a complex B-type fabric interpreted to be the result of grain boundary sliding in mylonitic peridotites from the subcontinental mantle ${ }^{43}$. However, this interpretation is contentious since B-type fabrics have not yet been formed by grain boundary sliding in experiments ${ }^{44}$.

The texture of most of the above peridotites is granular to porphyroclastic with the exception of peridotites studied by Wang et al $^{32}$ that are strongly deformed at relatively low temperatures $\left(600-8500^{\circ} \mathrm{C}\right)$. The deformation conditions for the activation of B-type slip recorded in natural peridotite from subduction environment vary from low $\left(700^{\circ} \mathrm{C}\right.$ to

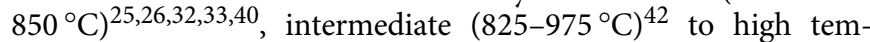
peratures $\left(1,000-1,250^{\circ} \mathrm{C}\right)^{27,30,31,39}$ over a range of estimated pressures from 0.8 to $4.27 \mathrm{GPa}$ (refs25-27,32,39,42), and estimated stress from 8 to $200 \mathrm{MPa}^{25,26,31}$. Experiments indicate that B-type fabrics are associated with higher temperature $\left(>1,400^{\circ} \mathrm{C}\right)$, stress $(>150 \mathrm{MPa})$ and pressure (1.6 to $11 \mathrm{GPa})^{16,17,19-21,24,35,36}$ conditions. The granular textured dunites from ISB lenses $\mathrm{A}$ and $\mathrm{B}$ have estimated pressure $(\sim 2.0 \mathrm{GPa})$ and temperature $\left(\sim 850^{\circ} \mathrm{C}\right)$ conditions ${ }^{14}$ that overlap the pressure temperature conditions recorded in natural peridotites from subduction environments.

The spatial and temporal relationship of natural B-type fabrics with mantle rocks in supra-subduction tectonic environments, combined with a robust explanation of this relationship from experiment and numerical modelling, lead us to conclude that the ISB dunites of lenses A and B represent mantle rocks deformed in a supra-subduction fore-arc setting. Their current position within a belt of $\sim 3,720 \mathrm{Myr}$ deformation represents the tectonic juxtaposition of these mantle slivers within what has been interpreted as a dismembered Eoarchaean ophiolite formed by the interaction of island arc terranes at convergent plate boundaries $^{6}$; an interpretation based on field, petrological and geochemical data. The development of the studied part of ISB started around 3,720 Myr with the proposed rupture of the oceanic crust and the formation of island arc magmas (Fig. 5a,b). The present position of the mantle material within ISB is related to an active subduction (Fig. 5). This convergence led to crustal thickening with the intercalation of upper mantle rocks (peridotites) within crustal rocks, such as layered gabbros and ultramafic rocks (Fig. 5b-d). The contact between mantle and crustal rocks is mylonitic and predate the $3,800 \mathrm{Myr}$ tonalite/ trondhjemites that engulf the ultramafic and mafic rocks ${ }^{46,47}$ (Fig. 5e,f). The continuing collision of crustal segments lead to further thickening and to generation of tonalite-trodhjemitegranodiorite/dacite volcanic complexes ${ }^{45}$ (Fig. 5e).

The high forsterite content $\left(\mathrm{Fo}_{90-96}\right)$ of olivine supports a strongly depleted upper mantle origin. The high-field strength element enriched signature retained in titanoclinohumite of the dunites provide evidence of subcrustal fluid fluxing processes associated with coeval crustal rocks with high-field strength element depletion, all of which are consistent with a subduction signature $6,12,48$. These dunites are also associated with deformed amphibolites that geochemically resemble boninites, island arc tholeiites and picrites 7,11 , lavas that are typically linked to a supra-subduction mantle source ${ }^{49,50}$. 
a

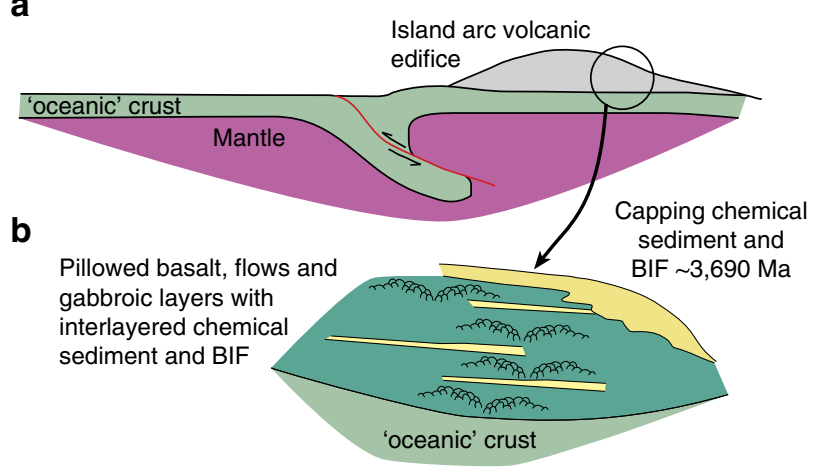

C

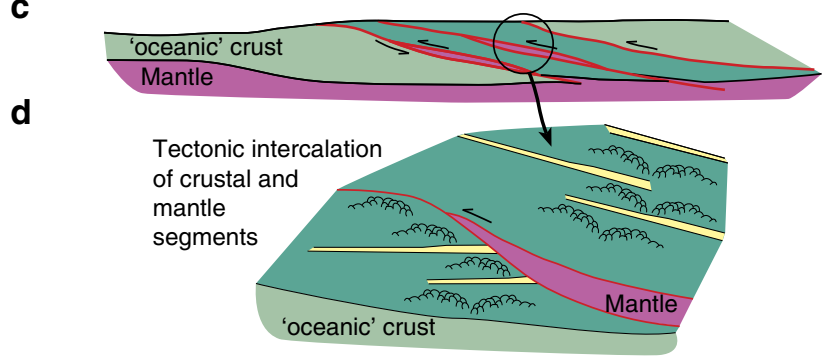

e

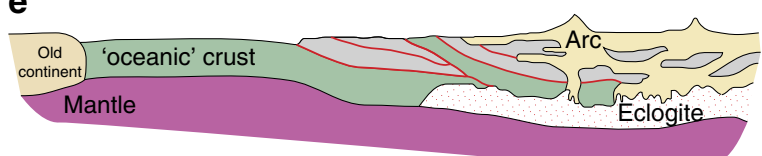

f

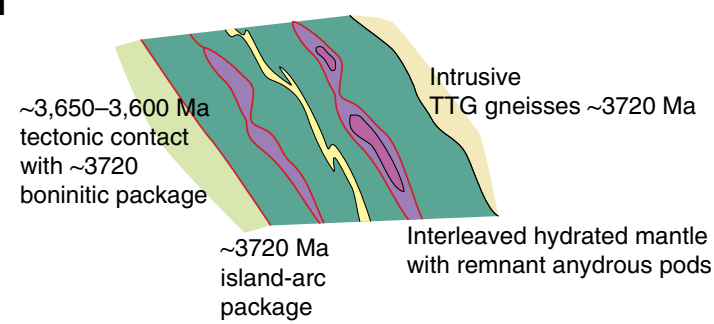

Figure 5 | Schematic cross-sections representing the tectonic evolution of the subduction through time. (a) $\sim 3,720$ Myr formation of island arc magmas ${ }^{11}$. Rupture of the oceanic crust and early subduction allows mantle melting and formation island arc. (b) Schematic zoom section through $\sim 3,720 \mathrm{Myr}$ island arc edifice showing the intercalation of magmatic rocks with sediments and band iron formation (BIF) dated at $\sim 3,690 \mathrm{Myr}$ (ref. 11). In some place, basalts formed pillows. (c) At $\sim 3,720-3,700 \mathrm{Myr}$ the subduction creates intercalation of oceanic crust segments and arc volcanics including mantle material leading to thickening ${ }^{45}$. (d) Zoom of imbricated arc and mantle rock segments. (e) At $\sim 3,720-3,690 \mathrm{Myr}$ collision of crustal segments leading to further thickening and leading to generation of tonalite-trondhjemite-dacite (TTG)/dacite volcanic complexes $^{45}$. (f) Schematic cross section through NW Isua ${ }^{54}$. Red lines correspond to tectonic contacts.

In this study, all three Isua samples record B-type fabrics. However, in a supra-subduction environment (010)[100] A-type and (001)[100] E-type fabrics are the more commonly observed fabric types $25,27,30-32$, and in some case B-type can even be absent ${ }^{23,51,52}$. The progression of fabric-type development in the supra-subduction environment is therefore likely to be complex and it has been suggested that the earliest stage of fabric development, associated with subduction initiation, may be the formation of E-type fabrics ${ }^{51}$. If this is correct, it may indicate that the activation of B-type slip system in Isua dunite may represent deformation in a more mature, advanced subduction setting. Isua mantle rocks may therefore record other fabric types that would help to piece together the geodynamic evolution of these enigmatic, ancient mantle bodies.

The LPOs preserved in the Isua lenses A and B dunites represent the oldest known fabrics regarded as exclusive to mantle rocks and thereby are consistent with the operation of Eoarchaean subduction proposed from the geochemistry of the intercalated mafic crustal rocks. The nature and style of this subduction remains controversial ${ }^{3,5}$. However, our results indicate that Isua lenses $A$ and $B$ dunites, even disassembled from their original lithological association (Fig. 5), preserve a valuable record of Eoarchaean mantle processes as well as evidence that the subduction factory was already in operation during the Eoarchaean era. Since subduction is the major mechanism of recycling material from the Earth surface back into deep mantle, including water and other volatiles ${ }^{1,2}$, the initiation of global recycling and development of top-down chemical heterogeneities in the mantle ${ }^{53}$ started during the Eoarchaean

\section{Methods}

Electron backscatter diffraction. Petrographic sections were polished during $4 \mathrm{~h}$ with $0.06 \mu \mathrm{m}$ colloidal silica $\mathrm{NaOH}$ (pH 9.8) to remove mechanically induced surface damage. Crystallographic orientations of olivine were collected using a Zeiss Evo 40XVP at Curtin University (Perth, Australia) and a Tescan Mira LMU at the University of Lausanne, Institute for Earth and Environmental Sciences (ISTE) (Switzerland). There were no observable inconsistencies in the data obtained from the different SEMs. Automatic EBSD mapping and manual data collection were done using the CHANNEL 5.10 software by Oxford instruments. Crystallographic orientation maps were obtained by collecting Electron Backscatter Patterns (EBSPs) over a regular grid with a $30-\mu \mathrm{m}$ step size. The EBSD data were noise reduced using a 'wildspike' correction and a five-neighbour zero solution extrapolation. At each of these steps, the resulting orientation maps were compared with band contrast maps to ensure that the noise reduction did not compromise the data.

Pole figures of crystallographic orientation of olivine have been plotted using the Oxford CHANNEL 5.10 software. Bulk fabric data of olivine are represented using average Euler angles for each grain (one point per grain) to avoid overrepresentation of large grains in thin sections. J-index was calculated to quantify $\mathrm{CPO}$ strength ${ }^{55}$ using D. Mainprice software (CareWare UNICEF programs) where 1 represents a random distribution.

X-ray computed tomography. X-ray CT was carried out using a Bruker SkyScan 1,173 at the University of Lausanne, ISTE (Switzerland). The peak accelerating voltage was $130 \mathrm{kV}$, exposure was $800 \mathrm{~ms}$, slice thickness $0.225 \mu \mathrm{m}$, for a pixel size of 24.9 and a X-ray tube current $60 \mathrm{nA}$. CTVox and Dataviewer softwares were used for data processing.

\section{References}

1. Conrad, C. P. \& Lithgow-Bertelloni, C. How mantle slabs drive plate tectonics. Science 298, 207 (2002).

2. Rupke, L. H., Morgan, J. P., Hort, M. \& Connolly, J. A. D. Serpentine and the subduction zone water cycle. Earth Planet. Sci. Lett. 223, 17-34 (2004).

3. Stern, R. J. Evidence from ophiolites, blueschists, and ultrahigh-pressure metamorphic terranes that the modern episode of subduction tectonics began in Neoproterozoic time. Geology 33, 557-560 (2005).

4. Condie, K. C. \& Pease, V. When did Plate Tectonics Begin on Planet Earth? Vol. 440 (Geological Society of America, 2008).

5. van Hunen, J. \& Moyen, J. F. Archean subduction: fact or fiction? Annu. Rev. Earth Planet. Sci. 40, 195-219 (2012).

6. Friend, C. R. L. \& Nutman, A. P. Eoarchean ophiolites? New evidence for the debate on the Isua supracrustal belt, Southern West Greenland. Am. J. Sci. 310, 826-861 (2010).

7. Polat, A., Hofmann, A. W. \& Rosing, M. T. Boninite-like volcanic rocks in the 3.7-3.8 Ga Isua greenstone belt, West Greenland: geochemical evidence for intra-oceanic subduction zone processes in the early Earth. Chem. Geol. 184, 231-254 (2002).

8. Myers, J. S. Protoliths of the 3.8 -3.7 Ga Isua greenstone belt, West Greenland. Precambrian. Res. 105, 129-141 (2001).

9. Nutman, A. et al. $\geq 3,850 \mathrm{Ma}$ BIF and mafic inclusions in the early Archaean Itsaq Gneiss Complex around Akilia, southern West Greenland? 
The difficulties of precise dating of zircon-free protoliths in migmatites. Precambrian. Res. 117, 185-224 (2002).

10. Nutman, A., Allaart, J. H., Bridgwater, D., Dimroth, E. \& Rosing, M. T. Stratigraphic and geochemical evidence for the depositional environment of the early Archaean Isua supracrustal belt, southern West Greenland. Precambrian. Res. 25, 365-396 (1984).

11. Polat, A. \& Hofmann, A. W. Alteration and geochemical patterns in the 3.7-3.8 Ga Isua greenstone belt, West Greenland. Precambrian. Res. 126, 197-218 (2003).

12. Friend, C. R. L. \& Nutman, A. P. Dunites from Isua, Greenland: a ca. 3,720 Ma window into subcrustal metasomatism of depleted mantle. Geology 39, 663-666 (2011).

13. Nutman, A. et al. Eoarchaean crustal growth in West Greenland (Itsaq Gneiss Complex) and in northeastern China (Anshan area): review and synthesis. Earth Accretion. Syst. Space Time 318, 127-154 (2009).

14. O'Neill, H. S. The transition between spinel lherzolite and garnet lherzolite, and its use as a geobarometer. Contrib. Mineral. Petrol. 77, 185-194 (1981).

15. Dilek, Y. \& Polat, A. Suprasubduction zone ophiolites and Archean tectonics. Geology 36, 431-432 (2008).

16. Jung, H. \& Karato, S. I. Water-induced fabric transitions in olivine. Science 293, 1460-1464 (2001).

17. Jung, H., Katayama, I., Jiang, Z., Hiraga, T. \& Karato, S. I. Effect of water and stress on the lattice-preferred orientation of olivine. Tectonophysics 421, 1-22 (2006).

18. Raterron, P., Chen, J., Li, L., Weidner, D. \& Cordier, P. Pressure-induced slip-system transition in forsterite: Single-crystal rheological properties at mantle pressure and temperature. Am. Mineral. 92, 1436-1445 (2007).

19. Couvy, H. et al. Shear deformation experiments of fosterite at $11 \mathrm{GPa}-1,400{ }^{\circ} \mathrm{C}$ in the multianvil apparatus. Eur. J. Mineral. 16, 877-889 (2004).

20. Jung, H., Mo, W. \& Green, H. W. Upper mantle seismic anisotropy resulting from pressure-induced slip transition in olivine. Nat. Geosci. 2, 73-77 (2009).

21. Ohuchi, T. \& Irifune, T. Development of A-type olivine fabric in water-rich deep upper mantle. Earth Planet. Sci. Lett. 362, 20-30 (2013).

22. Yang, K. et al. Relation between mantle shear zone deformation and metasomatism in spinel peridotite xenoliths of Jeju Island (South Korea): evidence from olivine CPO and trace elements. J. Geodyn. 50, 424-440 (2010).

23. Soustelle, V., Tommasi, A., Demouchy, S. \& Franz, L. Melt-rock interactions, deformation, hydration and seismic properties in the sub-arc lithospheric mantle inferred from xenoliths from seamounts near Lihir, Papua New Guinea. Tectonophysics 608, 330-345 (2013).

24. Katayama, I. \& Karato, S. Effect of temperature on the B- to C-type olivine fabric transition and implications for flow pattern in subduction zones. Phys. Earth Planet. Inter. 157, 33-45 (2006).

25. Kim, D. \& Jung, H. Deformation microstructures of olivine and chlorite in chlorite peridotites from Almklovdalen in the Western Gneiss Region, southwest Norway, and implications for seismic anisotropy. Int. Geol. Rev. 56, 1-19 (2014).

26. Skemer, P., Katayama, I. \& Karato, S. I. Deformation fabrics of the Cima di Gagnone peridotite massif, Central Alps, Switzerland: evidence of deformation at low temperatures in the presence of water. Contrib. Mineral. Petrol. 152, 43-51 (2006).

27. Park, Y. \& Jung, H. Deformation microstructures of olivine and pyroxene in mantle xenoliths in Shanwang, eastern China, near the convergent plate margin, and implications for seismic anisotropy. Int. Geol. Rev. 56, $1-21$ (2014).

28. Michibayashi, K. et al. Variable microstructure of peridotite samples from the southern Mariana Trench: Evidence of a complex tectonic evolution. Tectonophysics 444, 111-118 (2007).

29. Jung, $\mathrm{H}$. Deformation fabrics of olivine in Val Malenco peridotite found in italy and implications for the seismic anisotropy in the upper mantle. Lithos 109, 341-349 (2009)

30. Hidas, K. et al. Geodynamic implications of flattened tabular equigranluar textured peridotites from the Bakony-Balaton Highland Volcanic Field (Western Hungary). J. Geodyn. 43, 484-503 (2007).

31. Tasaka, M., Michibayashi, K. \& Mainprice, D. B-type olivine fabrics developed in fore-arc side of the mantle wedge along subducting slab. Earth. Planet. Sci. Lett. 272, 747-757 (2008).

32. Wang, Q. et al. Pressure- and stress-induced fabric transition in olivine from peridotites in the Western Gneiss Region (Norway): implications for mantle seismic anisotropy. J. Metamor. Geol. 31, 93-111 (2012).

33. Mizukami, T., Wallis, S. R. \& Yamamoto, J. Natural examples of olivine lattice preferred orientation patterns with a flow-normal a-axis maximum. Nature 427, 432-436 (2004).

34. Muramoto, M., Michibayashi, K., Ando, J. \& Kagi, H. Rheological contrast between garnet and clinopyroxene in the mantle wedge: an example from
Higashi-akaishi peridotite mass, SW Japan. Phys. Earth Planet. Inter. 184, 14-33 (2011).

35. Raterron, P., Amiguet, E., Chen, J., Li, L. \& Cordier, P. Experimental deformation of olivine single crystals at mantle pressures and temperatures. Phys. Earth Planet. Inter. 172, 74-83 (2009).

36. Sundberg, M. \& Cooper, R. F. Crystallographic preferred orientation produced by diffusional creep of harzburgite: Effects of chemical interactions among phases during plastic flow. J. Geophys. Res. 113, B12208 (2008).

37. Kneller, E. A., van Keken, P. E., Karato, S. \& Park, J. B-type olivine fabric in the mantle wedge: Insights from high resolution non-Newtonian subduction zone models. Earth Planet. Sci. Lett. 237, 781-797 (2005).

38. Frese, K., Trommsdorff, V. \& Kunze, K. Olivine [100] normal to foliation: lattice preferred orientation in prograde garnet peridotite formed at high $\mathrm{H} 2 \mathrm{O}$ activity, Cima di Gagnone (Central Alps). Contrib. Mineral. Petrol. 145, 75-86 (2003).

39. Song, S. \& Su, L. Rheological properties of mantle peridotites at Yushigou in the north Qilian mountains and their implications for plate dynamics. Acta Geologica Sinica 72, 131-141 (1998).

40. Nagaya, T. et al. Dehydration breakdown of antigorite and the formation of B-type olivine CPO. Earth. Planet. Sci. Lett. 387, 67-76 (2014).

41. Cordellier, F., Boudier, F. \& Boullier, A. M. Structural study of the Almklovdalen peridotite massif (southern Norway). Tectonophysics 77, 257-281 (1981)

42. Webber, C. E., Little, T., Newman, J. \& Tikoff, B. Fabric superposition in upper mantle peridotite, Red Hills, New Zealand. J. Struct. Geol. 30, 1412-1428 (2008).

43. Precigout, J. \& Hirth, G. B-type olivine fabric induced by grain boundary sliding. Earth Planet. Sci. Lett. 395, 231-240 (2014).

44. Hansen, L. N., Zimmerman, M. E. \& Kohlstedt, D. L. The influence of microstructure on deformation of olivine in the grain-boundary sliding regime. J. Geophys. Res. 117, B09201 (2012).

45. Nutman, A. et al. 3,806 Ma Isua rhyolites and dacites affected by low temperatureEoarchaean surficial alteration: Earth's earliest weathering. Precambrian. Res. 268, 323-338 (2015).

46. Nutman, A., McGregor, V. R., Friend, C. R. L., Bennett, V. \& Kinny, P. The Itsaq Gneiss Complex of southern West Greenland; the world's most extensive record of early crustal evolution (3900-3600 Ma). Precambrian. Res 78, 1-39 (1996).

47. Friend, C. R. L., Bennett, V. \& Nutman, A. Abyssal peridotites $>3,800 \mathrm{Ma}$ from southern West Greenland: field relationships, petrography, geochronology, whole-rock and mineral chemistry of dunite and harzburgite inclusions in the Itsaq Gneiss Complex. Contrib. Mineral. Petrol. 143, 71-92 (2002).

48. Dymek, R. F., Brothers, S. C. \& Schiffries, C. M. Petrogenesis of Ultramafic Metamorphic Rocks from the 3800 Ma Isua Supracrustal Belt, West Greenland. J. Petrol. 29, 1353-1397 (1988).

49. Pearce, J. A., Lippard, S. J. \& Roberts, S. in Marginal Basin Geology: Volcanic and Associated Sedimentary and Tectonic Processes in Modern and Ancient arginal Basins Vol. 16 (eds Kokelaar, B. P. \& Howells, M. F.) 77-94 (Geological Society of London, 1984).

50. Bloomer, S. H. et al. in Active Margins and Marginals Basins of the Western Pacific Vol. 88 (eds Taylor, B. \& Natland, J.) 1-30 (American Geophysical Union, 1995).

51. Harigane, Y. et al. The earliest mantle fabrics formed during subduction zone infancy. Earth Planet. Sci. Lett. 377-378, 106-113 (2013).

52. Kaczmarek, M.-A., Jonda, L. \& Davies, H. L. Evidence of melting, melt percolation and deformation in a supra-subduction zone (Marum ophiolite complex, Papua New Guinea). Contrib. Mineral. Petrol. 170, 19 (2015).

53. Andersen, M. B. et al. The terrestrial uranium isotope cycle. Nature 517, 356-359 (2015)

54. Nutman, A. P. \& Friend, C. R. L. New1:20,000 scale geological maps, synthesis and history of investigation of the Isua supracrustal belt and adjacent orthogneisses, southernWestGreenland: a glimpse of Eoarchaean crust formation and orogeny. Precambrian. Res. 172, 189-211 (2009).

55. Bunge, H. J. Texture Analysis in Materials Sciences (Buttleworth, London, UK, 1982).

\section{Acknowledgements}

We thank Dr B. Pulitz for her help with the X-ray Computed Tomography and P. Vonlanthen for his help with EBSD thin-section scanning setup at the University of Lausanne. We thank Professor S.I. Karato and two anonymous reviewers for comments that significantly improved the manuscript. The Australian Research Council by Grants DP0878453, DP0342794, DP1201002, Curtin University, Perth Western Australia, the Chinese Academy of Geological Sciences and the GeoQuEST Research Centre of the University of Wollongong are gratefully thanked for supporting this project. M.-A.K. thanks the Swiss National Science Foundation (SNSF), for support from Ambizione fund NSF-26083906. This paper is a CCFS publication number 689. 


\section{Author contributions}

M.-A.K. and S.M.R. conceived the project and A.P.N., C.R.L.F., and V.C.B. provided the samples. M.-A.K. took the lead on data analysis and manuscript writing. All authors provided critical discussion of the data and ideas and gave input on the manuscript.

\section{Additional information}

Competing financial interests: The authors declare no competing financial interests.

Reprints and permission information is available online at http://npg.nature.com/ reprintsandpermissions/
How to cite this article: Kaczmarek, M.-A. et al. Earth's oldest mantle fabrics indicate Eoarchaean subduction. Nat. Commun. 7:10665 doi: 10.1038/ncomms10665 (2016).

(c) (i) This work is licensed under a Creative Commons Attribution 4.0 International License. The images or other third party material in this article are included in the article's Creative Commons license, unless indicated otherwise in the credit line; if the material is not included under the Creative Commons license, users will need to obtain permission from the license holder to reproduce the material. To view a copy of this license, visit http://creativecommons.org/licenses/by/4.0/ 